1943) who took a case from time to time to several colleagues, and simply asked their opinion on the digital tension, obtaining divergent answers.

I venture to suggest that if a strictly controlled experiment on these lines were carried out at a Clinical Society meeting, that not only would it be difficult to find a statistically significant correlation between the observations of different members, but also that the results, if displayed on a screen at the end of such a meeting, would provide much quiet fun for all. Naturally there would have to be a limit to the number of observers, for fear that the repeated palpation of the eye should reduce the tension,

I am aware that the method has still much support in this country, but, as says Abelard in his Sic et Non, "dubitando ad inquisitionem venimus : inquirendo veritatem percipimus."

Yours truly,

LEEDS, January 15, 1944.

JOHN Foster.

\title{
OBITUARY
}

\section{Lieut.-Col. A. E. J. LISTER}

Lieut.-Col. A. E. J. Lister, M.B., B.S.Lond., F.R.C.S., I.M.S.(Rtd.), died suddenly on December 21, 1943, at Stroud, Gloucestershire, to the great loss of the service and his many friends. He studied medicine at St. Bartholomew's Hospital and in Vienna, and passed the M.B., B.S.Lond., and conjoint examinations in 1900, held the Brackenbury Scholarship in Surgery, 1901, and obtained the first place in the competitive examination for the Indian Medical Service, at the end of the Netley Army Medical School course he gained prizes in hygiene, clinical medicine and surgery. Early in his service in India Lister was on active service in East Africa and Somaliland and was also on service during the War, 1914-18.

Before the last war he was Ophthalmic Surgeon to the King George's College at Lucknow, and also Hon. Surgeon to H.E. the Viceroy.

He was the author of the Ophthalmic Section of the Medical Annual, 1922-1929; appendix in Smith's extraction of cataract; " after effects of escape of vitreous in intra-capsular extraction of cataract"; "extraction of cataract in the capsule and after effects of escape of vitreous in intra-capsular extraction of cataract," Arch. of Ophthal., 1908; "some practical points in sclero-corneal trephining," Indian Med. Gaz., 1920 ; etc.

$\mathrm{He}$ was, however, handicapped with poor health and retired from 
the Service in 1920. He settled in Bristol and was appointed Hon. Consulting Surgeon to the Bristol Eye Dispensary, where he worked for many years, and did some consulting practicè. He retired on account of ill-health and went to live near Stroud.

As an old colleague and friend I would like to add a personal tribute to a man who served his profession so ably, and his friends so faithfully. He had a very keen mind, was a hard worker, read widely, and in other languages had kept himself up-to-date.

Lister was a doctor of the very best type, a true Christian gentleman, self effacing and unselfish, always ready to help in every good work. He was painstaking to a degree in treating his patients, and much loved by them both in India and in this country. He leaves a widow and a daughter.

\section{BERNARD HAMILTON ST. CLAIR ROBERTS}

Mr. Harrison Butler writes:-

I think that it was in 1911 that I first met Roberts, the beginning of a friendship that lasted till his death on December 19, 1943. This was when we were founding the Midland Ophthalmological Society. He was an original member and held the office of president in 1929 and 1930 . As secretary of the society I saw a great deal of him and learned to love his simple lovable nature, and to appreciate his devotion to his professión, and his determination never to miss an opportunity of gaining knowledge. He was rarely absent from the meetings of the Ophthalmological Society, the Oxford Congress, and the Midland Ophthalmological Society, and he will be greatly missed by his colleagues at future meetings. $\mathrm{He}$ did not often speak, but when he did he always showed a sound practical knowledge of ophthalmology. He had a retiring nature and did not publish much, but he made a study of ray-cataract which in the form of chain-maker's cataract used to be common at Cradley Heath, and so Roberts had a great experience at the Guest Hospital at Dudley of this form of cataract. His 'paper on this 'subject, published in this Journal, Voll. V, p. 210, 1921, was one of those which led to chain-maker's and puddler's cataract being scheduled under the Workmen's. Compensation Act. In 1.925 Roberts gave the Middlemore Lecture on "senile changes in the eye."

B. H. St. Clair Roberts was the son of a dental surgeon who practised in Dudley. He went to the Sebright School, Wolverley, and then studied medicine at the Birmingham University, qualify: ing in 1900. He became house surgeon to the Wolverhampton Eye Infirmary and then to the Birmingham Eye Hospital. He started prattice in Dudley and opened an eye department at the Dudley Dispensary. This was eventually removed to the Dudley Guest Hospital where Roberts became ophthalmic surgeon till 1940. In 1911 he was appointed surgeon to the Worcester City and County 


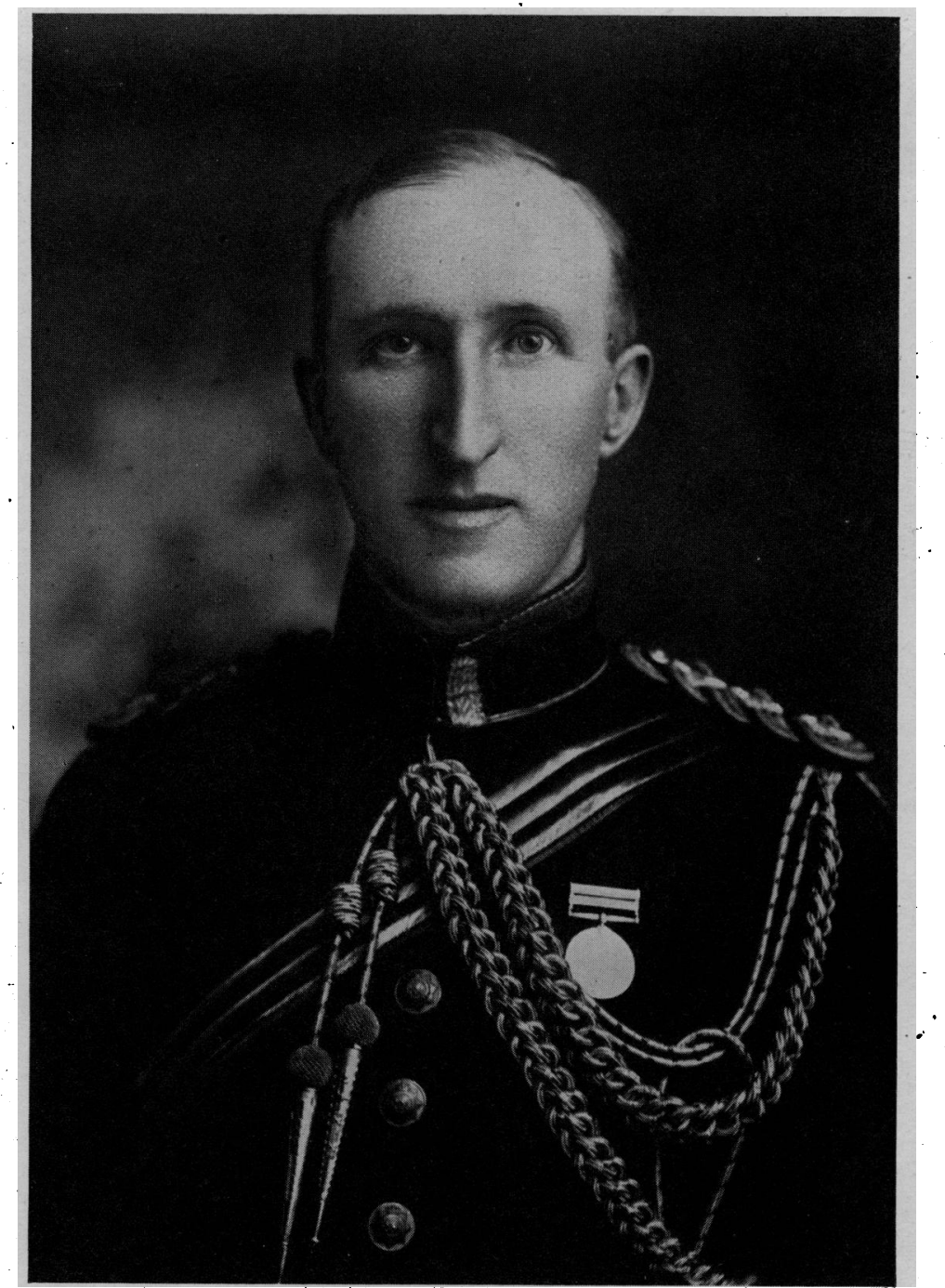

Photo by Bourna and Shepherd, India LIEUT-COL. A. E. J. LISTER 